\title{
THE ANTIDEMOCRATIC DRIFT IN THE EARLY 21ST CENTURY: SOME THOUGHTS ON ITS ROOTS, DYNAMICS AND PROSPECTS
}

\section{Dabrowski, $\mathbf{M}$.}

Marek Dabrowski / Non-Resident Fellow at Bruegel in Brussels; Professor at the Higher School of Economics in Moscow; Fellow at CASE - Center for Social and Economic Research in Warsaw; CASE - Center for Social and Economic Research, al. Jana Pawła II 61/212, 01-031 Warsaw, Poland. Email: marek.dabrowski@case-research.eu.

\begin{abstract}
In the first two decades of the 21st century, the previous democratization progress was partly reversed. It is well seen in the former Soviet Union and Central and Eastern Europe but also in other geographic regions. In search for causes of this warning trend, many authors point out economic factors such as economic stagnation, unemployment, inequality, consequences of the global financial crisis of 2007-2009 and side-effects of globalization. Not negating the role of economic factors, it is important, however, to see noneconomic determinants such as immature political institutions and their dysfunctionality, nationalism and cultural prejudices, and side-effects of the ICT revolution, which destroyed traditional media and public debate. The antidemocratic drift is dangerous not only for political and civil freedom but also has a negative impact on economic governance, making economies less open and competitive and easy victims of oligarchic predation ('crony' capitalism).
\end{abstract}

Keywords: market economy; democracy; economic freedom; political freedom; autocracy; post-communist transition; ICT revolution

JEL Classification: K40, P20, P26, P30, P37

\section{Introduction}

The last quarter of the 20th century was marked by the worldwide triumph of democracy. The democratic regimes replaced the autocratic ones in the Southern Europe, Latin America, many Asian and African countries, Central and Eastern Europe (CEE) and parts of the former Soviet Union (FSU). This often went in hand with market-oriented economic reforms and greater economic openness of individual countries. The optimist mood in respect to the sustainability of both trends dominated a public debate. For example, Fukuyama (1989) wrote about "...an unabashed victory of economic and political liberalism". 
Unfortunately, this optimism proved premature. The political developments in the first two decades of the 21st century brought new worrisome trends. Not only further progress in democratization has been stalled, but, in several countries, the previous democratization gains have been partly or totally rejected. Worse, democratic regress has been recorded not only in the so-called new democracies, that is, countries that built democratic regimes at the end of the 20th century. Deterioration in democratic standards of public life and governance has also been recorded, to various degrees, in countries which have much longer traditions of democracy and political freedom, including the United States (US) and Western Europe.

Many authors, representing both economic and political sciences, see the roots of this negative trend in an economic sphere. They often blame income and wealth inequalities (Alesina \& Perotti, 1996; Goodhart \& Pradhan, 2020), negative consequences of the global financial crisis (GFC) of 2007-2009 (Algan et al., 2017; Eichengreen, 2017; Zakaria, 2020), "hyper-globalization" (Rodrik, 2018, 2020) or other economic developments for triggering political instability and antidemocratic trends. However, such an economic "determinism" seems to be too narrow and simplified.

In our opinion, besides economic, there are also noneconomic factors that fuel antidemocratic and antiliberal sentiments, especially in their populist version, and help win them broader public support. Political forces and leaders who are engaged in undermining democratic and liberal standards refer not only to social and economic populism but quite often to nationalism, xenophobia, racism, religion values (in their own, sometimes very specific interpretation), imperial nostalgia, cultural traditionalism, etc. The revolution in information and communication technologies (ICT) in the last two and half decades, which destroyed the traditional media and public debate on the one hand, and opened new communication channels in the form of social media and internet fora, on the other, equipped antidemocratic populist leaders with new instruments of manipulating public opinion, biasing current events, spreading dubious news and mistrust against political adversaries and supposed enemies, with the aim of dividing and polarizing societies in their favour.

In this paper, we will try to provide a perspective of these mechanisms and instruments. The paper's purpose is to examine both the global and regional trends in political systems, discuss economic and noneconomic roots of antidemocratic populism, and analyze its dynamics. We also analyze the impact of antidemocratic drift in a political sphere on economic governance and policies.

Our analysis is concentrated on but not limited to the CEE/ FSU region. We also look at global trends and interrelations between political and economic spheres. Given the limited size of this paper, we are not able to offer a comprehensive and deep analysis of all factors that may influence antidemocratic tendencies and their impact on the quality of economic governance. Nor we are going to conduct a rigorous quantitative analysis with the use of econometric techniques. Rather this is a general overview of the analyzed trends and hypotheses on their potential causes and consequences. Most observations, hypotheses and conclusions presented in this paper have a tentative and conditional character and should be a subject of further research verification in future. 
Our paper starts with a historical overview of democratization trend globally and in the CEE/FSU region (Section 1). This is followed by a discussion on economic and noneconomic causes of the recent populist-cum-antidemocratic tendencies (Section 2). In Section 3 we present some observations on the dynamics of antidemocratic trends and speculate on the factors that could stop and reverse them. In Section 4 we look at the interrelations between political and economic freedom and try to figure out whether and how strongly the antidemocratic drift can damage economic policy and economic governance. The final part (Section 5) contains a summary of our analysis and conclusions.

The analytical narrative, which is supported by a simple statistical and correlation analysis, is the dominant methodological approach in our paper. However, one must remember that synthetic quantification of numerous qualitative characteristics of both economic and political systems (necessary to conduct cross-country comparison based on statistical analysis or examine the interdependence between economic and political variables) is always associated with the risk of misspecification and mismeasurement.

Cross-country surveys of economic and political freedom used in our analysis are based either on opinion polls of representatives of a business community or expert assessment, each of them unavoidably containing subjective judgments. Furthermore, most indices have a composite character. That is, they are constructed as a simple or weighted average of several detail components. This raises an additional methodological question on the composition of synthetic indices and weights attached to each individual component, potential autocorrelation between them. Nevertheless, and despite the mentioned methodological doubts, we believe that using the available numeric surveys, especially if they are conducted systematically for several years and by institutions that enjoy high professional reputation, may enrich our analysis as compared to the hypothetical variant based on a pure narrative.

\section{Historical trends}

Market economy (often called capitalism ${ }^{1}$ ) and democracy are relatively new phenomena in human history. The contemporary market economy understood as the system that is based on private ownership of means of production and freedom of economic activity (without privileges and restrictions typical for the feudal era), dates back to the beginning of the first industrial revolution, that is, the end of 18th century and early 19th century. Democracy, in a contemporary sense of this word, that is, the political regime which is based on a government accountable to voters, universal suffrage based on the principle of one person one vote, individual freedom and the rule of law is an even younger phenomenon built up during the 19th and early 20th century. In its complete and mature form, it appeared only at the beginning of the 20th century.

This time mismatch led to the situation when in its early stages, a system of the free-market economy (with a limited role of government) was accompanied by political regimes that, by today's standards, were either nondemocratic or only partly democratic. The universal franchise became a norm in Europe only after the WWI2.

\footnotetext{
${ }^{1}$ In this paper we use 'market economy' rather than 'capitalism' because the latter is historically associated with hot ideological debates and, therefore, contains sometimes unnecessary emotional content.

2 See Fukuyama (2015) for historical analysis of democratic systems.
} 
This changed gradually during the 20th century, with most of the high-income countries and several middle- and low-income countries having both democracy and a market economy (see Figure 1). The fastest growth in a number of democracies was recorded in the last quarter of the 20th century. This was the period of democratic transition in Latin America, South-East Asia, CEE, FSU and in African countries. Huntington (1991) called it a third wave of democratization.

Figure 1 | Number of democratic and autocratic political regimes, 1900-2018

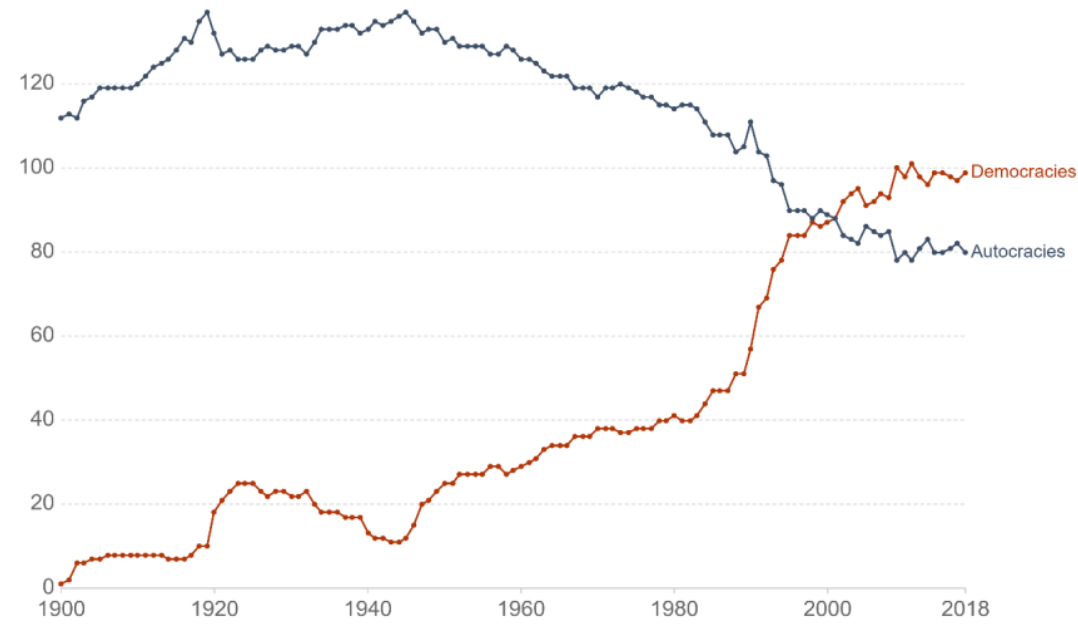

Note: Democracies are defined as the combination of both liberal and elected democracies. Autocracies are the sum of closed and elected autocracies.

Source: Roser (n.d.); Coppedge et al. (2019).

However, in the first two decades of the 21 st century, the progress stopped or, according to some metrics, was even partly reversed. This is clearly demonstrated by the most popular global political surveys - the Freedom House's Global Freedom Scores (FHGFS), the Bertelsmann Foundation's Transformation Index (BTI), and The Economist Intelligence Unit Democracy Index (EIUDI).

Figure 2 shows that between 2007 and 2017, the percentage of countries rated by the FHGFS as 'Free' and 'Partly Free' decreased, while the percentage of "Not-Free" countries increased. Correspondingly, between 2003 and 2017, the population in countries ranked as democracies by the BTI barely increased from 4.0 billion to 4.2 billion, while in countries ranked as autocracies, the number climbed from 2.3 billion to 3.3 billion (Bertelsmann, 2018).

The list of countries that recorded substantial deterioration in political rights and civil liberties since 2007 includes, among others, Azerbaijan, Bahrain, Burundi, Central African Republic, Congo (Brazzaville), Dominican Republic, Ethiopia, Gabon, Honduras, Hungary, Mali, Mauritania, Mexico, Nicaragua, Russia, Tajikistan, Turkey, Venezuela, and Yemen (Abramowitz, 2018).

This negative trend affected not only emerging-market and developing countries with a short historical record of political freedom and democracy ('new democracies'), but also 
some developed countries considered as stable democracies that suffered from the wave of political populism. For example, scores for the US deteriorated in HFGFS, BTI and EIUDI (EIU, 2021) surveys.

Figure 2 | The percentage of countries rated by Freedom House as 'Free', 'Partly Free' and 'Non-Free', 1987-2017

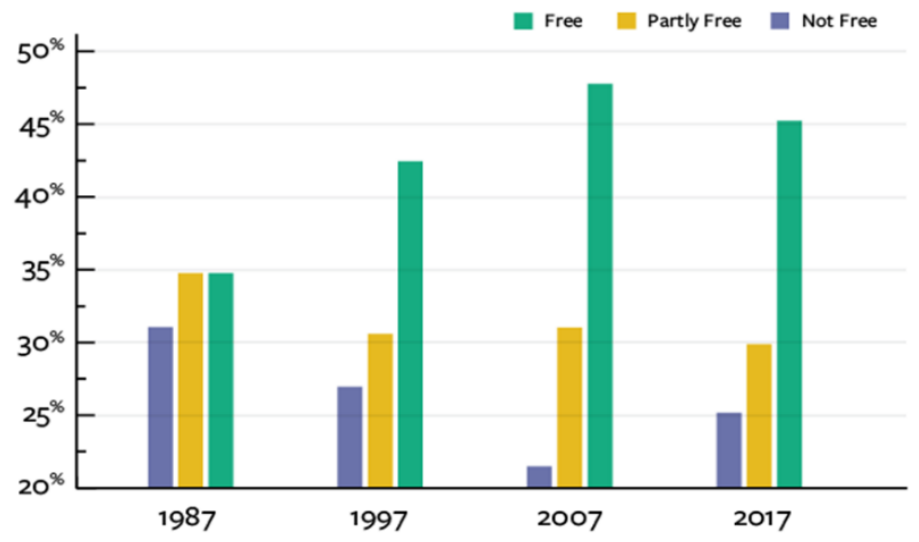

Source: Abramowitz (2018)

When one analyses the antidemocratic tendencies on the European Union's (EU) periphery and its closest neighbourhood, the situation looks equally or even more worrying, given the EU ambitions to set global standards of human rights, the rule of law and democratic governance ${ }^{3}$.

In CEE and the FSU, the collapse of communism at the end of the 1980s and early 1990s enabled the transition to democracy and a market economy. However, the democratic gains were reversed in Central Asia, part of the Southern Caucasus and Belarus already in the 1990s, and in Russia in the 2000s. In the 2010s, the antidemocratic drift hit part of CEE, including EU new member states and candidates such as Hungary, Poland, North Macedonia ${ }^{4}$ and Serbia.

Since the 1990s, the Freedom House has conducted a separate survey 'Nations in Transit' (FHNIT) for CEE and FSU countries, which includes seven subcategories - Electoral Process, National Democratic Governance, Civil Society, Local Democratic Governance, Independent Media, and Judicial Framework and Independence - summarized in the synthetic Democracy Score (DS) (Csaky \& Schenkkan, 2018).

Since 2007, the number of countries where the DS deteriorated has systematically exceeded the number of countries where it has improved (Figure 3). Figure 3 shows on the left axis the total number of changes and on the right axis the democracy score. The average and weighted average scores are for the democracy right axis. The negative trends in democracy concerned all subregions and all subcategories.

\footnotetext{
${ }^{3}$ Articles 2, 6 and 8 of the Treaty on European Union (TEU) - see https://eur-lex.europa.eu/legalcontent/EN/TXT/PDF/?uri=CELEX:02016M/TXT-20200301\&from $=\overline{E N}$

${ }^{4}$ North Macedonia succeeded in stopping and reversing this drift since 2017.
} 
Figure 3 | Changes in FHNIT Democracy Scores, 2005-2017

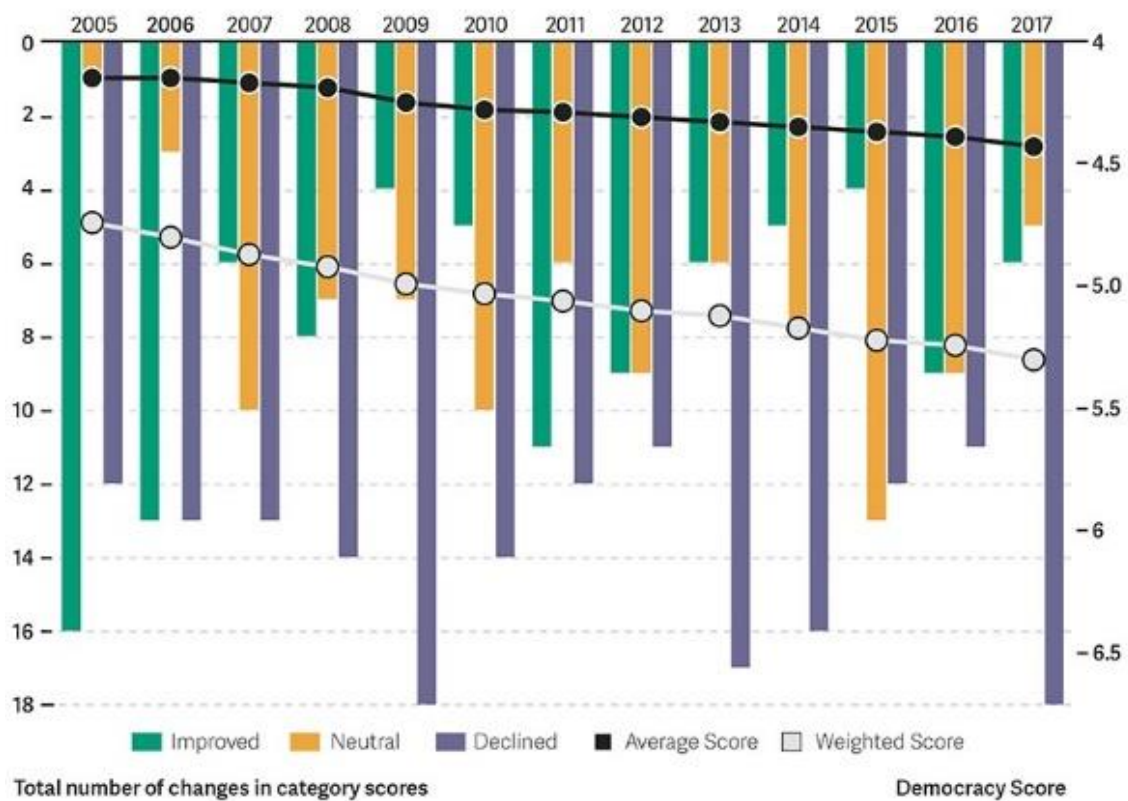

Source: Csaky and Schenkkan (2018)

Outside the FSU and CEE, the antidemocratic drift has also been visible in Turkey, where democratization progress of the early and mid-2000s was gradually reversed in the $2010 \mathrm{~s}$.

In the Southern neighbourhood of the EU, the Arab Spring of 2010-2011 raised hopes for democratization of the Middle East and North Africa (MENA) region. Unfortunately, these hopes were short-lived. Ten years later, only Tunisia managed to join the club of 'free' countries. The situation elsewhere deteriorated dramatically, including the accession of military dictatorship in Egypt, the outbreak of civil wars in Syria, Libya, Yemen and Iraq, and the crisis of confessional democracy in Lebanon. In 2018-2019, popular protests led to resignations of long-ruling dictators in Algeria and Sudan but have not yet brought about visible democratization progress (Dabrowski \& Dominguez-Jimenez, 2021).

A bit further South, in the Sub-Saharan Africa, after the democratization wave of the 1990s one can also observe antidemocratic backlash. For example, constitutional term limits for presidents have been lifted in several countries (The Economist, 2021).

\section{Beyond economic determinism: economic and noneconomic determinants of antidemocratic drift}

Explanation of the worldwide populist and antidemocratic drift in the two first decades of the 21 st century is not an easy task. Most frequently, both economists and political scientist investigate the economic causes of this drift. This is a dominating approach in both 
academic literature and popular debate, which draws from the tradition of a classical political economy or even more - from its Marxist offspring. 5

While we do not pretend to offer a comprehensive overview of all existing economic explanations of the recent populist and antidemocratic drift, we will just mention a few popular hypotheses.

First, the roots of an antidemocratic backlash are perceived to arise from the supposedly high and increasing income and wealth inequalities within individual countries. Quite often, this causality is taken for granted and without detailed empirical evidence - see, e.g., Goodhart and Pradhan (2020). The well-known analyses of populist policies in Latin America in the 1970s and 1980s have also been attributed to high income and wealth inequalities in this region (Dornbusch \& Edwards, 1991; Sachs, 1989) with such diagnosis based on stylized facts instead of a statistical and econometric examination of causal relations.

Other researchers try to demonstrate a positive statistical correlation between income inequality and specific populist/antidemocratic choices of the electorate - see Darvas (2016) on results of the Brexit referendum in the UK and Darvas and Efstathiou (2016) on results on the US presidential election in November 2016. However, correlation does not necessarily mean a causal relationship.

There are also authors who examine the impact of income inequality on democracy and its stability using rigorous econometric analysis. For example, Alesina and Perotti (1996) conclude that 'income inequality, by fueling social discontent, increases sociopolitical instability.' Muller (1988) demonstrates that extreme income inequalities frequently lead to the breakup of democratic regimes. However, this research concerns earlier decades (1960-1985 in the case of Alesina and Perotti, and 1960-1980 in the case of Muller) than the period of our interest and does not cover, therefore the CEE and FSU regions.

When we look at contemporary incidences of antidemocratic and populist backlashes, we will find countries (Figures 4 and 5) with high and increasing Gini coefficient of income inequality in the range of 35-40 (Russia in the early 2000s, the US in mid-2010s), very high (above 40) but declining Gini (Brazil and Turkey in mid-2010s), moderate (between 30 and 35) and stable or slowly declining Gini in the UK, Poland and Serbia in mid-2010s, low (below 30) and largely stable Gini in Hungary in 2010. That is, the actual level of income inequalities and their supposed rapid increase cannot easily serve as an explanation of the populist outbreak and democratic backsliding in the analyzed group of countries except the US and perhaps Russia.

Second, some authors try to explain the populist and antidemocratic wave by the deterioration of economic conditions in the aftermath of the global financial crisis (GFC) of 2007-2009 or the European financial crisis (EFC) of 2010-2015. For example, Zakaria (2020) claims that the economic and social consequences of the GFC gave a boost to the right-wing populism in 'the West' (p. 10). The same author also suggests that 'without credit

${ }^{5}$ In versions of Marxist institutional theory changes in an economic 'base' determine changes in social, political, cultural and institutional 'superstructure'. 
default swaps ${ }^{6}$, there might never have been a President Donald Trump' (Zakaria, 2020, p. 11). This sounds like an interesting hypothesis but stands without evidence of causality.

Figure 4 | Gini coefficient of net income inequality: Brazil, Turkey, UK and US, 1990-2019
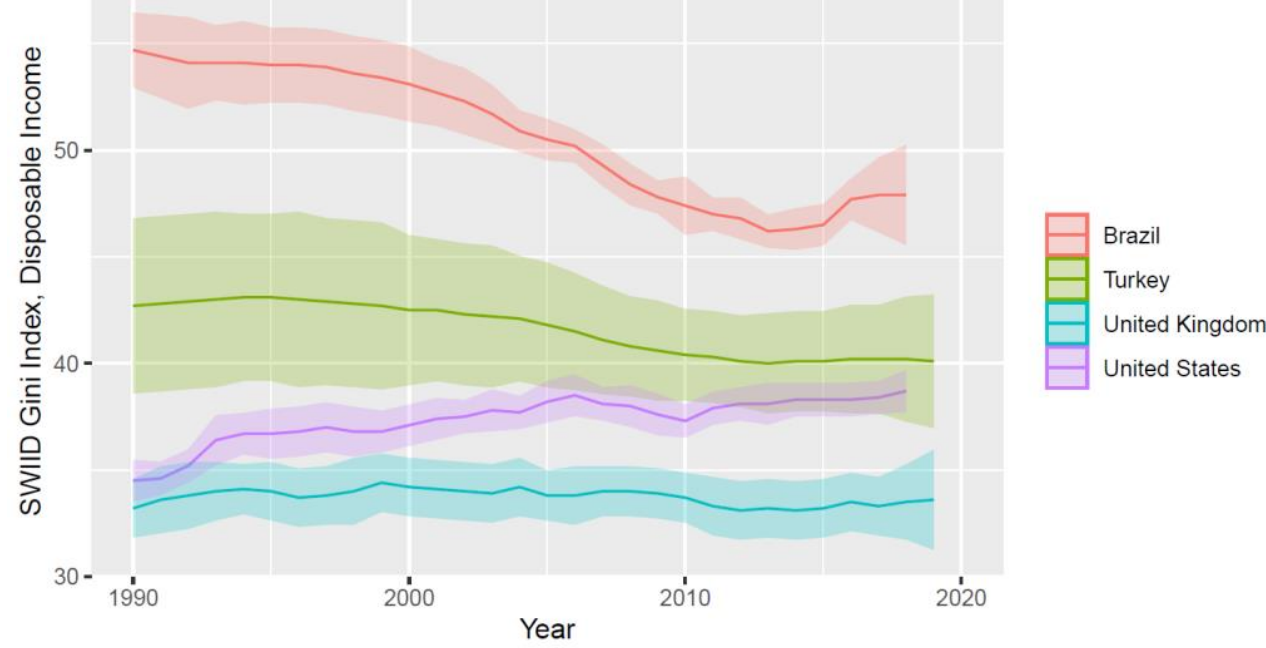

Figure 5 | Gini coefficient of net income inequality: Hungary, Poland, Russia and Serbia, 1990-2019

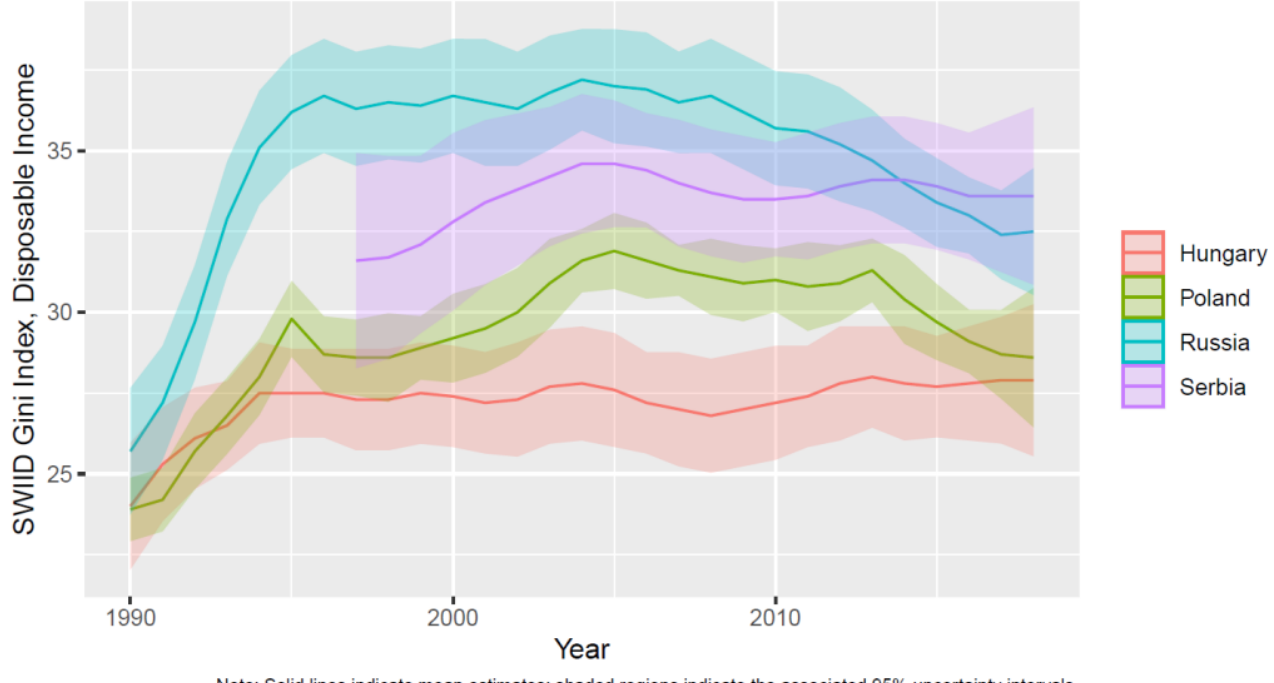

Note: Solid lines indicate mean estimates; shaded regions indicate the associated $95 \%$ uncertainty intervals

Source: Standardized World Income Inequality Database v9.0 (Solt 2020).

${ }^{6}$ A financial instrument, which became popular in the early and mid-2000s and which some analysts and commentators made responsible for the GFC (which we consider as a simplified diagnosis). 
Dustmann et al. (2017) find a positive relationship between adverse macroeconomic shocks and electoral support for populist countries in the EU15 (the so-called old member states) in the early and mid-2010s, especially in Southern Europe (which was most heavily hit by both GFC and EFC). However, other factors such as cultural ones also play a role.

Guiso et al. $(2017,2018)$, in their analysis, demonstrate the positive statistical relationship between the perception of economic insecurity and voters' preference for populist parties in the period following GFC and EFC. Both perceptions of economic insecurity and voting preferences are analyzed based on the European Social Survey individual database. Economic insecurity is measured (Guiso et al., 2017) by the experience of unemployment in the last five years, difficulties to live on current incomes, and type of employment, industry and skill level (as affected by exposure to globalization). On the one hand, these seem to be objective measures of economic wellbeing that can influence voters' attitude to political parties, policy views, and government-offered programs. On the other hand, they reflect respondents' individual perception rather than the objective socio-economic statistics. The former can differ from the latter, the fundamental problem that will be discussed below.

Algan et al. (2017) also find a strong statistical relationship between increasing unemployment (as a result of GFC and EFC) and voting for populist parties.

Going further back, that is, examining the period of 1870-2014 in Europe, Funke et al. (2016) found that after financial crises, political polarization of societies increased as well as the popularity of the far-right parties. A narrative historical analysis of the impact of major economic downturns, in the US and Europe, on the rise of populism is also provided by Eichengreen (2017).

However, if we look at the list of countries where populist and antidemocratic parties, leaders and ideas made progress in the first two decades of the 21 st century, we will find those that experienced serious economic problems at the moment of populist/antidemocratic backlash (Russia in 1999-2000, North Macedonia in 2006, Hungary in 2010, Serbia in 2012, Greece in 2015, Brazil in 2018, Italy in 2018) and those that have done relatively well economically (the UK and US in 2016, Poland in 2015, Philippines in 2016). The case of Turkey is a bit more complicated. The Justice and Development Party (AKP) led by Recep Tayyip Erdogan, came to power in 2002, just a year after a severe financial crisis. However, in the first decade of staying in power, it carried out prodemocratic and pro-European policies. When democratic backsliding started in 2012-2013, the Turkish economy was booming, so it is difficult to find an economic explanation of this radical policy change.

Third, another popular viewpoint is that globalization is responsible for de-industrialization in advanced economies and resulting 'pauperization' of part of a middle class, in particular, skilled blue-collars. Guiso et al. (2018) find structural changes caused by globalization (called by them the 'China effect') as fueling populist sentiments in EU 'old' member states but not in the EU 'new' member states in CEE.

On the other hand, Rodrik (2018, 2020) blames excessive globalization (which he calls 'hyper-globalization') not only for de-industrialization in advanced economies but also for undermining the sovereignty of national states that triggers nationalistic backlash. 
Increasing immigration pressures on Europe and the US (both economic migration and refugee flows) can also be considered as one of the globalization channels, even if part of this is triggered by noneconomic push factors such as violent conflicts or climate changes. Migrants can put downward pressures on wages and salaries of local low-skill workers and decrease their bargaining power, although this potential effect does not always find empirical support (see Dadush, 2018). The shrinking working-age population in most advanced economies is a counterbalancing factor and, more generally, constitutes a strong economic argument in favour of immigration.

Despite its economic rationale, immigration or fear of immigration ${ }^{7}$ is frequently used by right-wing populist forces and autocratic leaders as a useful instrument of mobilizing political support and consolidating their power. They have appealed to nationalism, xenophobia, and racism.

Overall, while we do not question the existence of economic determinants of populism and democratic backsliding, they are not the only ones in play. Concentrating on economic factors may lead to a one-sided diagnosis. Episodes of economic recession or stagnation, financial turbulences, excessive polarization of income and wealth, the crisis of welfare state, structural costs of globalization and technical innovations, and other economic difficulties also happened in the past and did not lead to such strong political polarization, at least not in advanced economies.

Therefore, the existence of noneconomic factors behind the recent wave of populism and democratic backsliding requires equally careful scrutiny, as do the economic ones. Below we overview only some of them.

Fukuyama (2018) analyzes the role of identity politics, which created a ground for modern populist nationalism and democracy backsliding.

One of the challenges to new democracies comes from the immaturity of their political and legal institutions, namely, an insufficient system of check and balances, a fragile political party system, and a lack of the tradition of the rule of law, etc. (see Rocha Menocal, 2013). New democracies also lack democratic traditions and confront various legacies of the autocratic/ non-democratic past (see Casper, 1995 in respect to the Philippines and Latin America).

Indeed, if we look at the political history of CEE, democratic traditions are largely absent. In the interwar period (1918-1938) only Czechoslovakia could be considered a democratic state. Autocratic or semi-autocratic regimes prevailed in other countries, sometimes after a relatively short period of parliamentary democracy (Bulgaria, Romania, Poland, Baltic states) defeated by autocratic coups. Even more, the argument of the deficit of democratic tradition and institutions can apply to 'new' democracies outside Europe, in Asia, Africa, and the Middle East.

However, it worth noting that among cases of antidemocratic drift, there are two countries (Hungary and Poland) which, by the early 2000s, managed to build advanced democratic and rule-of-law institutions. They were highly ranked by both the FHGFS and BTI and

${ }^{7}$ For example, in CEE countries where the number of immigrants and refugees is still limited as compared to Western Europe. 
additionally anchored in the EU acquis communautaire. This suggests that there are no perfect institutional guarantees against the antidemocratic backlash.

One of the factors, the role of which may remain underestimated in most analyses, relates to changes in the information industry, denoted here by ICT. The ICT revolution brought progress in every sphere of economic and social life, leading to substantial productivity gains, especially in the late 1990s and early 2000s. It also facilitated cultural, educational, and scientific globalization giving easy access to various information sources, global knowledge and expertise, and helped in the cooperation of people both across the borders and within individual nations.

However, there are also less understood and potentially negative side-effects of the ICT revolution. For example, the ICT revolution undermined traditional media, which served not only as of the source of daily information but also as the platform of political and professional debate and played an important public education role. Some traditional media disappeared; others moved to market niche occupied earlier by tabloids. In the era of the ICT revolution, information must be short, with sensational highlights, appeal to emotions, and can include promotion of feelings of insecurity, nationalism and xenophobia. Factual accuracy often plays a secondary role, and there lacks of focus on deeper analysis or even elementary factual dossiers. Paradoxically, in the era of increasing global interdependence, media information has become increasingly local. The headlines often appeal to populist and nationalistic sentiments and language to attract a bigger national niche audience. The same trend affects commercial advertising even by transnational corporations.

Another novelty in the media and public discourse space relates to the role of social media and various internet fora, which help people to connect with each other, exchange information and opinions, do business, or undertake spontaneous bottom-up initiatives. However, they often can be misused by both those who want to manipulate intentionally public opinion and political process and those who appear to be unprofessional, such as having a focus on conspiracy theories ${ }^{8}$. The general public faces difficulty in distinguishing real knowledge from misleading or false information (see Born, 2021).

Changes in media also have had a dramatic impact on politics. The decision-making horizon was shortened from years to weeks or days, from one opinion poll to another. Politics became a media arena in which "gladiators" fight each other and where deep polarization (using social and traditional tabloidized media) replaces political dialogue and search for compromise. This, in turn, gives opportunities for radical leaders who otherwise would remain on the political margin (see Eichengreen, 2017).

\footnotetext{
${ }^{8}$ Perhaps it is worth to quote the opinion of Umberto Eco: 'Social media gives legions of idiots the right to speak when they once only spoke at a bar after a glass of wine, without harming the community ... but now they have the same right to speak as a Nobel Prize winner. It's the invasion of the idiots' - see https://www.goodreads.com/quotes/9870044-social-media-gives-legions-of-idiots-the-right-to-speak I am grateful to Mario Mariniello for putting my attention to this quote.
} 


\section{The dynamic of antidemocratic regimes: no self- constraint can be expected}

Most of the contemporary antidemocratic regimes have come to power as a result of democratic elections. Military coups, once popular in Latin America, Africa, Middle East, Asia or even in the European periphery (Greece and Turkey in the post-WWII era), have become rather exceptional events in the 21 st century ${ }^{9}$.

The peaceful and constitutional way of obtaining political power by parties and leaders with autocratic ambitions appears to have consequences for the resilience of democratic institutions. First, in many instances, the antidemocratic agenda is not openly articulated; rather, it is hidden behind populist promises in the socio-economic sphere and nationalistic slogans. Therefore, at least part of the electorate may remain unaware of what and whom it really chooses.

Second, the victory of antidemocratic parties and leaders in a fair and free election gives them a strong argument for democratic legitimacy that is then used in removing or weakening systemic checks and balances. Here, international criticism of election results lacks a strong foundation, unlike in cases of constitutional and military coups.

Third, in a 'peaceful' scenario, antidemocratic changes are usually conducted in a gradual way through the removal of the existing checks and balances. Unlike in the case of military coups, when the change of political regime happens overnight, here the consolidation of political power is following a slower path - step by step. Such a process may take several years to take hold, as observed in Putin's Russia, Erdogan's Turkey, Orban's Hungary, Kaczynski's Poland or Vucic's Serbia.

The scenario of gradual implementation of an antidemocratic agenda may be misleading both for domestic public opinion and the international community: each individual step can be explained as a minor change without obvious fundamental importance. It also helps to adopt a 'salami' tactic against actual and potential opponents (each individual change targets only a selected constituency) and dilutes public awareness of the ongoing takeover of political power and erosion of political and civil liberties. When a wake-up call finally comes, it may be already too late to reverse autocratic drift in a peaceful way.

Antidemocratic parties and leaders usually start by targeting constitutional checks and balances ${ }^{10}$. They take over media (by government, state-controlled corporations and banks, and government-friendly oligarchs), constitutional courts, the judicial system, law enforcement agencies and public administration. They also dismantle the federal system, regional and local self-government by centralizing decisions. Furthermore, they put constraints on civil society organizations (including sources of their financing), limit civil rights (often by adopting antiterrorist legislation), establish ideological and political control over educational, academic, and cultural institutions. Once the most important checks and balances are removed or disabled, the time comes for changes in election legislation in favour of the ruling party/ leader. Finally, if it does not work, the election may just be

9 These exceptions include, among others, Egypt (2013), Mali (2012 and 2020), and Myanmar (2021).

10 This has been also tried by populist leaders in the US (Donald Trump) and UK (Boris Johnson - see The

Economist, 2020). 
seriously compromised, including the banning or arrest of opposition party leaders and falsifying election results.

As mentioned earlier, populist leaders and parties with autocratic agendas like to refer to popular support and democratic mandate. Their officially stated goal is to make the democratic regime more effective by removing unnecessary checks and balances and the veto power of minority groups. This is the justification behind the 'sovereign' democracy concept propagated by the Kremlin (Surkov, 2006), the 'illiberal' state or 'illiberal' democracy ${ }^{11}$ concept of Victor Orban (Toth, 2014), or the goal of overcoming 'legal impossibilism' by Jaroslaw Kaczynski (Davis, 2018).

However, official ideology or political declarations may be misleading: continuous consolidation and concentration of political power is the most important and ultimate goal of these regimes. Democracy is used as a cover for as long as it helps to keep and strengthen political control. Once the regime loses popularity and population support, it may not further risk a fair and free election. Then can come the turn to outright autocratic methods and repression. Giving up autocratic power means not only losing power-associated benefits and privileges but also creates a risk of being held legally responsible for the abuse of power, violating constitution and law, political repressions, power-related corruption, etc. The stake can be too high to risk such a scenario. Political developments in Belarus in 2020-2021 after the questionable presidential election well illustrate this scenario.

Elimination of systemic checks and balances makes an autocratic evolution easier, and this is the unavoidable fate of all variants of 'illiberal' or 'sovereign' democracy (Sadurski, 2019). The scenario of self-constraining autocracy appears to be highly unlikely.

When the elimination of constitutional checks and balances goes too far, the only effective challenge to the autocratic regime may originate from an economic or political shock. It may be a serious economic crisis like that in the Soviet Union in the second half of the 1980s and as in Indonesia in the 1997 bank crisis when there ensued the collapse of President Suharto's autocratic regime. Or the shock may be from a lost military conflict such as in the collapse of the Argentinian military junta after losing the Falkland war in 1982 and the collapse of the Milosevic regime in Serbia in 2000 after losing the Kosovo conflict in 1999. Other shocks are major social unrest caused by abuse of power, elections viewed as being rigged, or perceived corruption of the ruling elite. For these, consider the examples of the so-called colour revolutions in Georgia in 2003, Ukraine in 2004 and 2013-2014, Kyrgyzstan in 2005, 2010, and 2020, Armenia in 2018, and the Arab Spring of 2010-2011.

\section{Antidemocratic drift and economic governance}

In this section, we analyze whether the observed antidemocratic drift can lead to more government interference/dirigisme in business activity, less economic freedom and transparency and, as a result, more distortions and macroeconomic imbalances. ${ }^{12}$ The answer is, most likely, positive based on the observation of global interrelations between political and economic freedom and, even more, in the formerly centrally planned economies (CEE, FSU and Asia).

11 The term 'illiberal' democracy was first used by Zakaria (2002).

12 This section borrows extensively from Dabrowski (2018) and (2020). 
While historically, there were many cases of market-friendly autocracies (for example, in the 19th century - see Section 2), in the contemporary era, economic freedom is more frequently associated with political freedom than not (see Dabrowski, 2020).

Figure 6 plots the 2020 Heritage Foundation Index of Economic Freedom (HFIEF) against the 2020 FHGFS. The HFIEF is the synthetic measure of the degree of economic freedom, macroeconomic stability, and property rights protection in a scale from 0 (the least free) to 100 (the freest) $^{13}$. In turn, the FHGFS in its 2020 edition is the sum of political rights (maximum 40) and civil liberty (maximum 60) scores. That is, its scale runs from 0 (the least free) to 100 (the freest), similarly to the HFIEF. Both surveys present 2019 data.

Figure 6 | Interrelation between economic and political freedom in the world, 2019

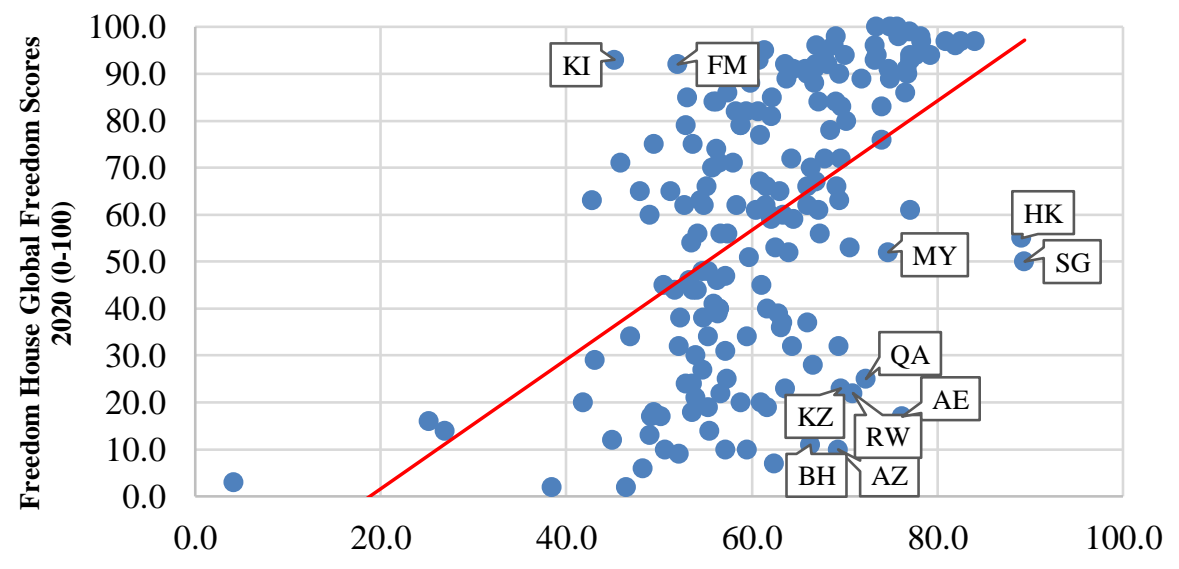

Heritage Foundation Index of Economic Freedom 2020 (1-100)

Source: Heritage.org, Freedomhouse.org

Figure 6 confirms a positive correlation between economic and political freedoms. However, there are outliers on both sides of the correlation line. Hong Kong, Singapore, the United Arab Emirates, Qatar, Rwanda, Bahrain, Malaysia, Azerbaijan, and Kazakhstan belong to the group of countries, which enjoy more economical than political freedom. One could say these are examples of market-friendly autocracies. Kiribati (KI) and Micronesia (FM), and some other countries represent the opposite asymmetry, that is, more political freedom and democracy than economic freedom.

The correlation is strong in the case of the former centrally planned economies. Three Baltic countries and Czechia occupy the top-right corner of Figure 7 - that is, they are the freest countries, both economically and politically. Turkmenistan and Tajikistan remain at the bottom of both ratings. There are outliers on both sides of the trend line. In Mongolia and Ukraine, the degree of political freedom substantially exceeds the degree of an economic one.

13 The HFIEF consists of 12 detail indexes related to property rights, judicial effectiveness, government integrity, tax burden, government spending, fiscal health, business freedom, labor freedom, monetary freedom, trade freedom, investment freedom and financial freedom 
There are even more countries on the opposite side of the trend line, that is, countries where the degree of economic freedom is substantially higher than a political one. It applies, in the first instance, to Azerbaijan and Kazakhstan and, to a lesser extent, to China, Russia, Belarus, Uzbekistan, and Vietnam.

Figure 7 also shows the limits of 'market-friendly autocracies': none country with a low political freedom score (below 30) belongs to the 'mostly free' category in the HFIEF (the score over 70). Belarus and Russia are at the bottom of the 'moderately free' category (between 60 and 70). China, Vietnam, Cambodia, Laos, Uzbekistan and Tajikistan belong to the economically 'mostly unfree' group (between 50 and 60). Turkmenistan is considered as a 'repressed' economy (below 50 scores).

Figure 7 | Interrelation between political and economic freedom in the formerly centrallyplanned economies of Europe and Asia, 2019

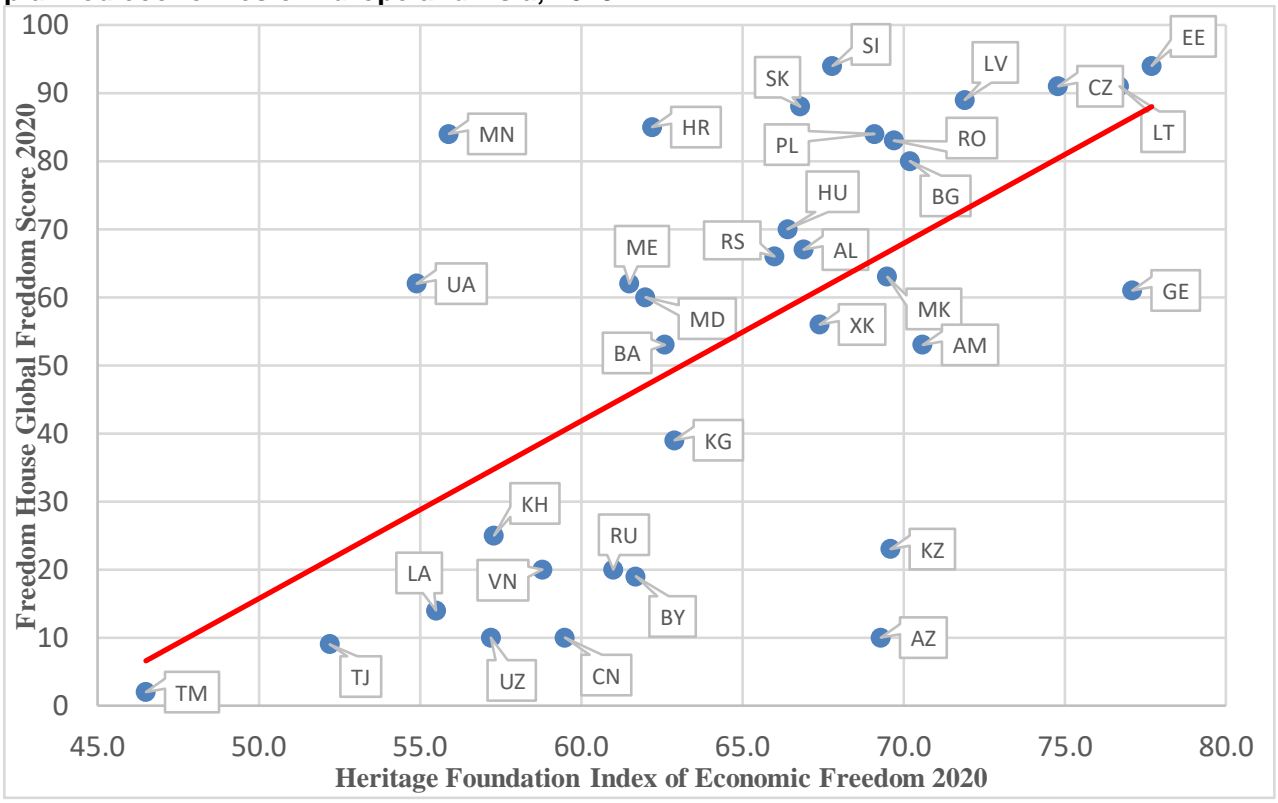

Source: Heritage.org, Freedomhouse.org

The correlation between economic and political freedom should not be surprising if one analyzes the impact of democratic mechanisms and institutions on market economy functioning (see, e.g., de Haan \& Sturm, 2003). The following arguments are the most important (Dabrowski, 2018, 2020):

1. The system of political checks and balances, which is the vital component of liberal democracy, limits concentration and abuse of political power (also in the economic sphere) and strengthens the rule of law.

2. Effective democratic institutions such as parliamentary and judicial control of the executive, free media, civil society organizations, the right of access to public information help to increase the transparency of government actions, constrain opportunities for corruption, rent-seeking, and the capture of state institutions by groups of interests. Therefore, they increase the effectiveness of government 
operations and regulations (Gable, 2005) and facilitate the stability of property rights.

3. Democratic rotation of political elites and their accountability to the electorate may also reduce the incidence of power abuses, corruption and state capture. Interestingly, some autocratic and semi-autocratic regimes have tried to ensure rotation of political elites in one-party states by introducing mandatory term limits (for example, in Mexico before 1988 and China between 1982 and 2018). However, in the absence of other checks and balances, such limits can be easily removed or circumvented, as it happened in China in 2018 and Russia in 2020.

4. Civil liberties support and supplement economic freedom. It is hard to imagine the effective functioning and development of a contemporary post-industrial (servicebased) economy without the freedom of movement, expression, speech, assembly, the rights to private property and privacy, equal treatment under the law, etc., and their effective judicial protection.

5. Governments that enjoy a democratic mandate and support can easier take difficult and unpopular decisions, which are required to avoid macroeconomic imbalances and ensure sustainable economic growth in a medium and long term

6. Countries with autocratic governments are usually less open to the external world than democratic ones (Gable, 2005), which has a negative impact on economic and social development.

The history of post-communist transitions in the CEE/FSU region clearly demonstrated the advantages of early democratization. ${ }^{14}$ Countries that democratized their political systems at the very beginning of transition were successful in limiting the influence of the old political elite. The latter consisted of the functionaries of the former communist parties, army, security service, old-style administration, and managers of state-owned enterprises (socalled 'red' directors), none of them enthusiasts of the market system.

In the 2000s and 2010s, antidemocratic drift usually led to greater corruption, state capture and an increasingly privileged position of oligarchs who were closely associated with the political power and government bureaucrats (Dabrowski, 2018, 2020).

A historical analysis of individual country stories shows that in cases of antidemocratic drift, market-oriented reforms were either stopped or reversed (Dabrowski, 2018, 2020). Among others, this has been the case of Slovakia (1994-1998), Belarus after 1996, Russia after 2003, Macedonia, Turkey and Hungary since the beginning of 2010s, Ukraine (2010-2014) and Poland after 2015. Outside the CEE/FSU region, one can mention Zimbabwe under the presidency of Robert Mugabe, Venezuela under the presidency of Hugo Chavez and Nicolas Maduro. In both cases, populist dictatorships have led to balance of payments crises and hyperinflations.

\footnotetext{
14 In China, Vietnam, Laos and Cambodia market reforms were initiated in late 1970s and 1980s by communist parties, which gradually departed from their Marxist-Leninist-Maoist orthodoxy in an economic sphere but retained monopoly on political power. However, economic reforms in these countries have not progressed beyond certain limits (see Figure 7) due to political constraints.
} 
There are also opposite cases. The collapse of autocratic/ semi-autocratic regimes and resulting progress in democratization enabled launching or a return to economic reforms in Slovakia after 1998, Serbia after 2000, Georgia after 2003, and Ukraine after 2014.

The above analysis suggests that the observed antidemocratic drift will have, most likely, a further negative impact on economic freedom and the quality of market institutions and economic policies. It may produce more market distortions, corruption, state capture, and less transparency in the conducted policies. In turn, it will lead to the system, which can be called 'crony' capitalism, the phenomenon already observed in Russia (Aslund, 2019), China (Pei, 2016), Turkey (Gurakar, 2016), several FSU countries, and Hungary (Buckley \& Byrne, 2017).

\section{Concluding remarks}

In this paper, we analyze the worrisome trend of democratic backsliding worldwide but with special attention given to new democracies in the CEE/ FSU region. Obviously, the question on the causes of this populist and antidemocratic drift becomes crucially important.

Most explanations in both economic and political science literature concentrate on economic factors such as high- and increasing-income inequalities, consequences of GFC and EFC, and side-effects of globalization. Not negating the significance of those factors, we believe they do not fully explain the rise of populism and antidemocratic backlash. Such a backlash has happened not only in countries that have suffered from the economic downturn and high unemployment, which have been hit by structural shocks caused by globalization and where income inequality has increased. On the contrary, several countries which have been affected by the populist-cum-antidemocratic drift have been doing economically well, with well-functioning welfare state institutions and with relatively low- and decreasing-income inequalities.

The above means that one must also look for noneconomic factors. Several of them are well-known, such as dysfunctional political institutions, insufficient checks and balances, the rule of law deficits, nationalism, racism and xenophobia, social conservatism, imperial nostalgia (in case of countries, which lost or are about to lose their past geopolitical status), territorial revisionism, ethnic and sectarian divide, etc. All of these can fuel populism, but they are not novel. As in the case of economic factors discussed above, they already existed earlier. Thus, why did they start to dominate domestic and (also partly) international politics in the first two decades of the 21 st century but not earlier?

Our hypothesis points out the role of the ICT revolution as the factor, which has radically reshaped public debate, political life and political systems. The disappearance of traditional media on the one hand, and the expansion of social media and the internet, on the other, gave a floor to radical politicians and movements who otherwise would remain on the margin of political life. Comprehensive analyses and balanced public debates were replaced by arenas with a dominance of demagogy and personal attacks. Uncontrolled social media, internet fora and internet portals create room for spreading disinformation, hate, manipulating public opinion, influencing people's feelings and appealing to low motives. Even if a country's economy is performing well, it is not so difficult to convince the electorate, by means of manipulation, that the situation is opposite to what the facts indicate. 
This hypothesis on the role of uncontrolled information technology requires further examination and empirical verification. It is also important to find effective solutions to address this problem without compromising freedom of speech and the positive effects of the ICT revolution. We are not ready to offer such solutions yet but believe it is necessary to recognize that the communication revolution appears to be a major outlet for developing political radicalism and extremism.

Looking ahead, it may be implausible to hope that emerging autocratic regimes can be selfconstraining and will not tend towards establishing full political control over society. There may be no benevolent autocrats. Their populist reference to the 'will' of the people and to a democratic mandate appears to be purely instrumental for use as long as social support for it exists. When it ends, soft and populist autocracy can be replaced by a tough and traditional one, with falsified elections and the use of coercive measures against political opposition and those who do not support a ruling party and leader. In support of this case are the evolution of Lukashenko's regime in Belarus, Putin's regime in Russia, and Erdogan's regime in Turkey.

There are countries that managed to stop the populist and antidemocratic drift, such as the US, Greece, Italy, North Macedonia and Ukraine. This appears to have been possible thanks to either strength of constitutional checks and balances, weakness and political mistakes of populist leaders/ ruling parties, or to massive social resistance.

In contemporary societies, economic and political freedoms are increasingly interconnected. Democracy and market economy can support each other. This is particularly true in the CEE and FSU regions. Therefore, autocratic tendencies observed in these and other regions are likely to negatively affect the quality of economic policy and economic governance. Economic systems of countries where the democratic system is in retreat may suffer from even more distortions. They may then more easily evolve towards the crony capitalism model in which there is a close symbiosis between political and business elite, both being afraid of genuine competition and the country's openness.

The COVID-19 pandemic inevitably created constraints on political freedom and civil liberties practically almost everywhere (see EUI, 2021). One may only hope that they will be lifted as soon as the pandemic threat disappears. However, this is not so obvious in countries that experienced antidemocratic drift before the pandemic. Autocratic rulers can try to exploit this emergency to accelerate the consolidation of their power, neutralize opposition, and dismantle remaining check and balances. This might be the case currently in China, Vietnam, Belarus, Russia, Azerbaijan, Turkey, Hungary, and Poland.

\section{References}

Abramowitz, M. J. (2018). Freedom in the World 2018: Democracy in Crisis. Freedom House. https://freedomhouse.org/report/freedom-world/freedom-world-2018.

Algan, Y., Guriev, S., Papaioannou, E., \& Passari, E. (2017). The European Trust Crisis and the Rise of Populism. Brookings Papers on Economic Activity, BPEA Conference Drafts, September 78, https://spire.sciencespo.fr/hdl:/2441/2i9jel1usb85nr2j7tejsaldfu/resources/2017-algan-gurievpapaioannou-passari-the-european-trust-crisis-and-the-rise-of-populism.pdf

Aslund, A. (2019). Russia's Crony Capitalism: The Path from Market Economy to Kleptocracy. Yale University Press. 
Alesina, A., \& Perotti, R. (1996). Income Distribution, Political Instability and Investment. European Economic Review, 40(6), 1203-1228. https://doi.org/10.1016/0014-2921(95)00030-5

Bertelsmann. (2018). Democracy under Pressure: Polarization and Repression Are Increasing Worldwide, Bertelsmann Stiftung, Press Release, 22 March. https://www.bertelsmannstiftung.de/en/press/press-releases/press-release/pid/democracy-under-pressure-polarizationand-repression-are-increasing-worldwide/

Born, K. (2021). Can Digital Disinformation Be Disarmed? Project Syndicate, January 29. https://www.project-syndicate.org/onpoint/how-to-stop-disinformation-on-social-mediaplatforms-by-kelly-born-2021-01

Buckley, N., \& Byrne, A. (2017). Viktor Orban's oligarchs: a new elite emerges in Hungary. Financial Times, December 21. https://www.ft.com/content/ecf6fb4e-d900-11e7-a039-c64b1c09b482

Casper, G. (1995). Fragile Democracies: The Legacies of Authoritarian Rule, Pitt Series in Policy and Institutional Studies. University of Pittsburgh Press.

Coppedge, M., Gerring, J., Knutsen, C. H., Lindberg, S. I., Teorell, J., Altman, D., Bernhard, M., Fish, M. S., Glynn, A., Hicken, A., Lührmann, A., Marquardt, K. L., McMann, K., Paxton, P., Pemstein, D., Seim, B., Sigman, R., Skaaning, S.-E., Staton, J., Wilson, S., Cornell, A., Gastaldi, L., Gjerløw, H., Ilchenko, N., Krusell, J., Maxwell, L., Mechkova, V., Medzihorsky, J., Pernes, J., von Römer, J., Stepanova, N., Sundström, A., Tzelgov, E., Wang, Y., Wig, T, \& Ziblatt, D. (2019). V-Dem [Country-Year/Country-Date] Dataset v9. Varieties of Democracy (VDem) Project. https://doi.org/10.23696/vdemcy19

Csaky, Z., \& Schenkkan, N. (2018). Nations in Transit 2018: Confronting Illiberalism. Freedom House, https://freedomhouse.org/report/nations-transit/nations-transit-2018

Dabrowski, M. (2018). Are economic and political freedoms interrelated? Bruegel blog, October 10, 2018, http://bruegel.org/2018/10/are-economic-and-political-freedoms-interrelated/

Dabrowski, M. (2020). Interdependence between economic governance and political power: the case of post-communist countries. Paper presented at the International Workshop on 'Variety of Power in the Economy' organized by the Laboratory for Studies in Economic Sociology, Higher School of Economics, Moscow, July 3-4. https://ecsoclab.hse.ru/en/ecsocworkshop/

Dabrowski, M., \& Dominguez-Jimenez, M. (2021). Economic crisis in the Middle East and North Africa. Bruegel Policy Contribution, January 21, https://www.bruegel.org/wpcontent/uploads/2021/01/PC-02-2021-220121.pdf

Dadush, U. (2018). The economic effects of refugee return. Economics Discussion Paper, February 26. Kiel Institute for the World Economy, http://www.economicsejournal.org/economics/discussionpapers/2018-22

Darvas, Z. (2016). Brexit vote boosts case for inclusive growth. Bruegel blog, July 13, http://bruegel.org/2016/07/brexit-vote-boosts-case-for-inclusive-growth/

Darvas, Z., \& Efstathiou, K. (2016). Income inequality boosted Trump vote. Bruegel blog, November 9. http://bruegel.org/2016/11/income-inequality-boosted-trump-vote/

Davis, C. (2018). Hostile Takeover: How Law and Justice Captured Poland's Courts. Freedom House, Analytical Brief. https://freedomhouse.org/report/analytical-brief/2018/hostile-takeover-how-lawand-justice-captured-polands-courts

de Haan, J., \& Sturm, J.-E. (2003). Does More Democracy Lead to Greater Economic Freedom? New Evidence for Developing Countries. European Journal of Political Economy, 19(3), 547-563, September. https://doi.org/10.1016/S0176-2680(03)00013-2 
Dornbusch, R., \& Edwards, S. (1991). Macroeconomic Populism in Latin America. NBER Working Paper, No. 2986. http://www.nber.org/papers/w2986.pdf

Dustmann, C., Eichengreen, B., Otten, S., Sapir, A., Tabellini, G., \& Zoega, G. (2017). Europe's Trust Deficit: Causes and Remedies. Monitoring International Integration, 1.

Eichengreen, B. (2017). Trump Before Trump. Project Syndicate, January 12. https://www.projectsyndicate.org/commentary/trump-political-forebear-enoch-powell-by-barry-eichengreen-2017$\underline{01}$

EIU. (2021). Democracy Index 2020. In sickness and in health? The Economist Economic Intelligence Unit. www.eiu.com

Freedomhouse.org. Countries and Territories. https://freedomhouse.org/countries/freedomworld/scores

Fukuyama, F. (1989). The End of History? The National Interest, 16(1989), 3-18. http://www.jstor.org/stable/24027184.

Fukuyama, F. (2018). Identity. Contemporary Identity Politics and the Struggle for Recognition. Profile Books.

Funke, M., Schularick, M., \& Trebesch, C. (2016). Going to the extremes: Politics after financial crises, 1870-2014. European Economic Review, 88, 227-260.

Gable, S. (2005). The effect of democracy on different categories of economic freedom. European Journal of Political Economy, 21(4), 967-980. https://doi.org/10.1016/j.ejpoleco.2004.11.005

Goodhart, C., \& Pradhan, M. (2020). The Great Demographic Reversal: Aging Societies, Waning Inequality and Inflation Revival. Palgrave Macmillan. https://link.springer.com/book/10.1007\%2F978-3-030-42657-6

Guiso, L., Herrera, H., Morelli, M., \& Sonno, T. (2017). The spread of populism in Western countries. Vox. EU, October 14. https://voxeu.org/article/spread-populism-western-countries

Guiso, L., Herrera, H., Morelli, M., \& Sonno, T. (2018). The populism backlash: An economically driven backlash. Vox.EU, May 18. https://voxeu.org/article/populism-backlash-economically-drivenbacklash

Gurakar, E. C. (2016). Politics of Favoritism in Public Procurement in Turkey: Reconfigurations of Dependency Networks in the AKP Era. Palgrave Macmillan US. https://www.palgrave.com/gp/book/9781137592750\#aboutBook

Heritage.org. (2020). Country Rankings: World \& Global Economy Rankings on Economic Freedom. https://www.heritage.org/index/ranking

Huntington, S. P. (1991). Democracy's Third Wave. Journal of Democracy, Spring, 12-34, https://www.ned.org/docs/Samuel-P-Huntington-Democracy-Third-Wave.pdf

Muller, E. N. (1988). Democracy, Economic Development, and Income Inequality. American Sociological Review, 53(1), 50-68. http://www.jstor.org/stable/2095732

Pei, M. (2016). China's Crony Capitalism: The Dynamics of Regime Decay. Cambridge, MA and Harvard University Press. https://www.hup.harvard.edu/catalog.php?isbn=9780674737297

Rocha Menocal, A. (2013). Emerging democracies: Rising to the challenge. ODI Briefing, No. 84, November, Oversea Development Institute. https://www.odi.org/sites/odi.org.uk/files/odiassets/publications-opinion-files/8699.pdf 
Rodrik, D. (2018). Populism and the economics of globalization. Journal of International Business Policy, 1(1-2), 12-33. https://link.springer.com/content/pdf/10.1057/s42214-018-0001-4.pdf

Rodrik, D. (2020). Why Does Globalization Fuel Populism? Economics, Culture, and the Rise of RightWing Populism. https://drodrik.scholar.harvard.edu/files/danirodrik/files/why does globalization fuel populism september 2020.pdf

Roser, M. (n.d.). Democracy. Our World in Data. https://ourworldindata.org/democracy\#all-chartspreview

Sachs, J. D. (1989). Social Conflict and Populist Policies in Latin America. NBER Working Paper, No. 2897 (March). http://www.nber.org/papers/w2897.pdf

Sadurski, W. (2019). Poland's Constitutional Breakdown. Oxford Scholarship Online. https://oxford.universitypressscholarship.com/view/10.1093/oso/9780198840503.001.0001/oso $\underline{-9780198840503}$

Surkov, V. (2006). Nasha rossijskaya model' demokratii nazyvaetsya "suverennoj demokratiei" (Our Russian model of democracy is called "sovereign democracy", Transcript of the speech of the Deputy Head of Presidential Administration and Assistant to the President of the Russian Federation Vladislav Surkov for the students of the Center for the Party Education and Personnel Training of the 'United Russia' Party, February 7, https://web.archive.org/web/20080212215743/http://www.edinros.ru/news.html?id=111148

The Economist. (2020). The constitution: Dominic Cummings and the unchained ministers. The Economist, November 21. https://www.economist.com/britain/2020/11/19/dominic-cummingsand-the-unchained-ministers

The Economist. (2021). Time out: Too many African countries are letting presidential term limits slip. The Economist, January 9. https://www.economist.com/leaders/2021/01/09/too-many-africancountries-are-letting-presidential-term-limits-slip

Toth, C. (2014). Full text of Viktor Orbán's speech at Băile Tuşnad (Tusnádfürdö) of 26 July 2014, The Budapest Beacon, October 13th, 2013 - April 13th, 2018, https://budapestbeacon.com/full-textof-viktor-orbans-speech-at-baile-tusnad-tusnadfurdo-of-26-july-2014/

Zakaria, F. (2020). Ten Lessons for a Post-Pandemic World. New York, NY: W.W. Norton \& Company.

The discussion paper passed the review process. | Received: February 23, 2021; Revised: April 23, 2021; Accepted: May 19, 2021; Published: June 1, 2021. 